\title{
Outdoor Thermal Environment of High-rise Residential Area
}

\author{
Meng Zhen ${ }^{1 *}$, Dian Zhou ${ }^{2}$ \\ ${ }^{1,2}$ Department of Architecture, School of Human Settlements and Civil Engineering, Xi an Jiaotong \\ University, Xi'an, Shaanxi 710049, China \\ *Corresponding author, Meng Zhen, zhenmeng@xjtu.edu.cn
}

\begin{abstract}
We conduct field tests on residential areas in Xi'an, such as construction dooryard, tree, water and square. Second, we conducted a questionnaire survey on residents' outdoor thermal comfort and collected residents' subjective thermal responses. The results of the study showed that during the daytime, the trees had a good cooling effect, and their cooling capacity could reach $6.53^{\circ} \mathrm{C}$ (referenced to measurements close to pine trees). During the night hours, water bodies, square and construction dooryard all had good cooling effect. Their cooling capacities were $8.47^{\circ} \mathrm{C}, 5.31^{\circ} \mathrm{C}$ and $5.9^{\circ} \mathrm{C}$ respectively based on measurements close to pine trees. This shows that the ability of cooling by small areas of water, building overhead layer and building patios, which is more effective at night. It shows that reasonable building layout could improve the wind environment, small areas of water contribute little to improve air humidity, and customs can affect people's thermal adaptability.
\end{abstract}

\section{Introduction}

Due to the development of China's "Belt and Road" initiative, Xi'an, as a core node city, plays an irreplaceable role in economic and environmental issues. Therefore, the environmental issues of governance in Xi'an City (urban heat islands, haze, energy consumption) are issues that we need to resolve urgently. Scholars have conducted outstanding research on the world-wide urban environmental issues, such as haze, heat waves, thermal uncomfortable (Johansson, 2006; Hong, 2015; Salata, 2017; Golasi, 2016; Sharmin, 2015; Li, 2016; Jamei, 2016), and research shows that the spatial form of residential area, the material of the underlying surface, the greening rate, and water have a profound impact on the residential microclimate (Syafii, 2016; Taleghani, 2015).

Scholars have done less research on the outdoor thermal environment in the cold regions of northwestern China (take Xi'an as an example). However, it is of great significance for architects to have well understanding of the outdoor thermal environment in cold regions of northwest China. Xi'an city has very hot surface temperature during summer days. The maximum average surface temperature of $67^{\circ} \mathrm{C}$ on 19 July 2017 in Xi' an was the highest temperature in the country at that time and would be of great significance to research. China's urban housing has been developing in the direction of "high altitude, high density and high intensity". However, the existing urban outdoor thermal environment research paid little attention to the cities in northwestern China, especially the basin cities with outstanding microclimate problems in Xi'an. In addition, the current literature uses software simulation methods to study the quantitative relationship between air temperature and thermal comfort. There is a lack of subjective investigation on residents' thermal sensation. The paper believes that interviewing residents with different life backgrounds is an important method to study thermal comfort. This paper applies field test combined with questionnaire survey to study outdoor thermal environment of Xi'an. (Xi, 2017; Lai, 2014; Chen, 2016; Ding, 2017; Wang, 2018; Yu, 2017).

The building overhead layer area can provide residents with a place for cooling, social interaction and rest, and can provide shade and increase local wind speed (Tong, 2017). The lawn can beautify and cool the outdoor environment, but the mowed lawn can lose the ability to fix $\mathrm{CO}_{2}$ with the added cost of manpower and material. The plaza area can create a space for residents to walk and play with children. The water body can improve the microclimate of residential areas. The trees can lower the outdoor temperature through transpiration, shade, etc. and improve the outdoor microclimate. These outdoor design elements can create different microclimates, which in turn can affect residents' thermal comfort. (Tan, 2017; Wong, 2017; Tong, 2018; Liu, 2017; Wu, 2017; Lee, 2018)

The purpose of this paper is to study the urban outdoor thermal environment and residents' outdoor thermal comfort in high-rise residential areas in Xi'an, China. The research was divided into three steps: (i): The field monitoring was conducted on typical dwelling districts in Xi'an, a cold region in northwest China. The monitoring include temperature, relative humidity, wind speed and globe temperature. (ii): A questionnaire survey of residents' thermal comfort and thermal sensation was conducted to collect subjective data. (iii): Statistical analysis of measured data and questionnaire results were conduct.

\section{Xi'an Climate and Research Area}

$\mathrm{Xi}^{\prime}$ an is an ancient capital with a long history. It is located between $107.40^{\circ} \mathrm{N} \sim 109.49^{\circ} \mathrm{N}$ and $33.42^{\circ} \mathrm{E} \sim 34.45^{\circ} \mathrm{E}$. The highest calculated temperature is $35^{\circ} \mathrm{C}$ in July, and the lowest calculated temperature is $-5.7^{\circ} \mathrm{C}$ in January, the temperature and humidity data of Xi'an in 2017 are shown 
below (Figure 1). The maximum temperature is $40^{\circ} \mathrm{C}$ (August) and the minimum temperature is $-7^{\circ} \mathrm{C}$ (December)

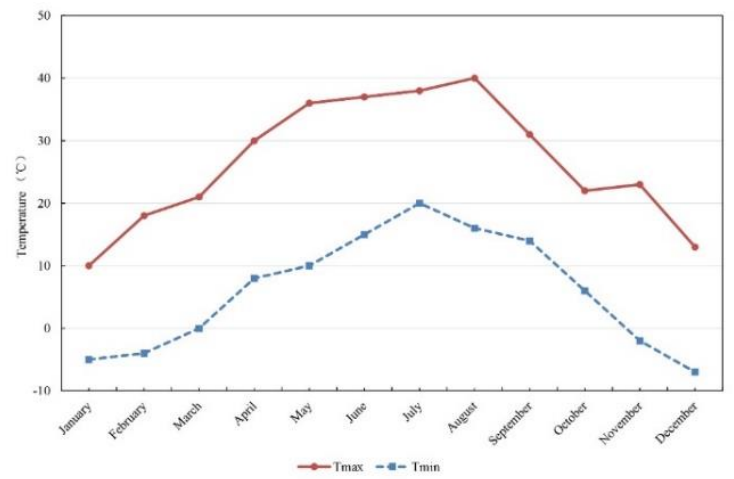

Figure 1: Temperature and Humidity in Xi'an, 2017.

Xi'an is a city in the cold zone with four seasons. The research selected the Qujiang Liveable Community as a representative area for actual monitoring to study the outdoor temperature levels of different underlying surfaces. The research site was Qujiang Liveable Community. The measured objects include different outdoor design elements such as building overhead layer area, water bodies, trees and residential squares in urban area, so to discover the outdoor thermal environment factors. Figure 2 shows the location of our study to illustrate the relationship of these design elements and residents' thermal comfort.

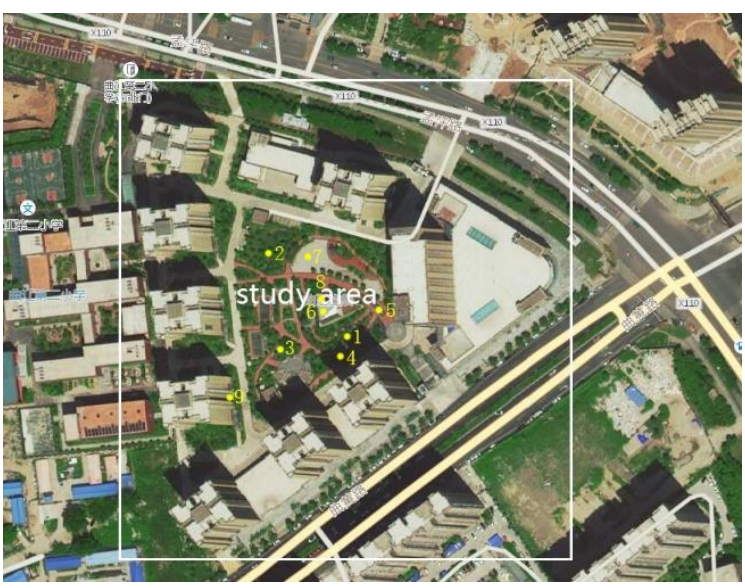

Figure 2: Measured residential area.

\section{Method}

\section{Field test}

The research team conducted field tests on the outdoor thermal environment of the Qujiang Liveable Community from 25th to 30th July 2017 (Figure 2). A total of 9 monitoring locations were set up. The measuring height was $1.5 \mathrm{~m}$ (Table 1) from the ground at the monitoring site. One minute of data was automatically recorded. The physical properties and contents of the underlying surface were as shown in Table 2. The monitoring equipment parameters are as shown in Table 3.
Table 1: Distribution of measurement locations.

\begin{tabular}{|c|c|}
\hline Locations & Measurement location description \\
\hline Location 1 & The Cooling Effect of Chinese pagoda trees \\
\hline Location 2 & The cooling effect of maple trees \\
\hline Location 3 & The cooling effect of horse chestnut trees \\
\hline Location 4 & The cooling effect of pine trees \\
\hline Location 5 & Cooling effect from a water body \\
\hline Location 6 & Iron roof temperature level \\
\hline Location 7 & The temperature level of a residential square \\
\hline Location 8 & Cooling effect of an building overhead layer \\
\hline Location 9 & Cooling effect of construction dooryard \\
\hline
\end{tabular}

Table 2: Monitoring parameters.

\begin{tabular}{|l|c|c|c|c|c|}
\hline Locations & $\begin{array}{c}\text { Underlay } \\
\text { surface } \\
\text { properties }\end{array}$ & $\mathbf{T}_{\mathbf{a}}$ & $\mathbf{R H}$ & $\mathbf{V}$ & $\mathbf{G}$ \\
\hline Location 1 & Soil & $\sqrt{ }$ & $\sqrt{ }$ & $\sqrt{ }$ & $\sqrt{ }$ \\
\hline Location 2 & Soil & $\sqrt{ }$ & $\sqrt{ }$ & $\sqrt{ }$ & $\sqrt{ }$ \\
\hline Location 3 & Soil & $\sqrt{ }$ & $\sqrt{ }$ & $\sqrt{ }$ & $\sqrt{ }$ \\
\hline Location 4 & Soil & $\sqrt{ }$ & $\sqrt{ }$ & $\sqrt{ }$ & $\sqrt{ }$ \\
\hline Location 5 & Water & $\sqrt{ }$ & $\sqrt{ }$ & $\sqrt{ }$ & $\sqrt{ }$ \\
\hline Location 6 & Iron roof & $\sqrt{ }$ & $\sqrt{ }$ & $\sqrt{ }$ & $\sqrt{ }$ \\
\hline Location 7 & Concrete & $\sqrt{ }$ & $\sqrt{ }$ & $\sqrt{ }$ & $\sqrt{ }$ \\
\hline Location 8 & Concrete & $\sqrt{ }$ & $\sqrt{ }$ & $\sqrt{ }$ & $\sqrt{ }$ \\
\hline Location 9 & Concrete & $\sqrt{ }$ & $\sqrt{ }$ & $\sqrt{ }$ & $\sqrt{ }$ \\
\hline
\end{tabular}

Table 3: Measurement Equipment information.

\begin{tabular}{|c|c|c|}
\hline $\begin{array}{c}\text { Measurement } \\
\text { Equipment }\end{array}$ & $\begin{array}{c}\text { Type } \\
\text { (Manufacture) }\end{array}$ & Accuracy \\
\hline $\begin{array}{c}\text { Temperature and } \\
\text { humidity data } \\
\text { recorder }\end{array}$ & HOBO U23-001 & $\begin{array}{c}\text { Temperature: } \pm \\
0.18^{\circ} \mathrm{C} @ 25^{\circ} \mathrm{C} \\
\mathrm{RH}: \pm 2.5 \% \text { from } \\
10 \% \text { to } 90 \%\end{array}$ \\
\hline Wind speed & $\begin{array}{c}\text { HOBO H21 } \\
\text { meteorological } \\
\text { station }\end{array}$ & $\begin{array}{c}\text { Wind speed: } \\
\pm 4 \% \\
\text { Wind direction: } \\
\pm 5^{\circ}\end{array}$ \\
\hline $\begin{array}{c}\text { Globe } \\
\text { temperature }\end{array}$ & $\begin{array}{c}\text { SWEMA } \\
\text { Thermal Comfort }\end{array}$ & $\pm 0.5^{\circ} \mathrm{C}(10-$ \\
$\left.40^{\circ} \mathrm{C}\right)$
\end{tabular}

\section{Questionnaire}

On July 2017, the research team conducted an outdoor thermal comfort survey in Xi'an Qujiang Residential Area. The survey included thermal sensation vote (TSV) and thermal comfort vote (TCV). The survey population was mainly residents of Qujiang Liveable Community. Gender includes men and women. Age ranges include 1570 years old. These were taxi drivers, university teachers, retired employees and car drivers in the occupation background. Basically, they cover different occupational groups. Volunteers responded to the questionnaires in a sitting posture. A total of 70 questionnaires were distributed to residents (Table 4). 
Table 4: Questionnaire.

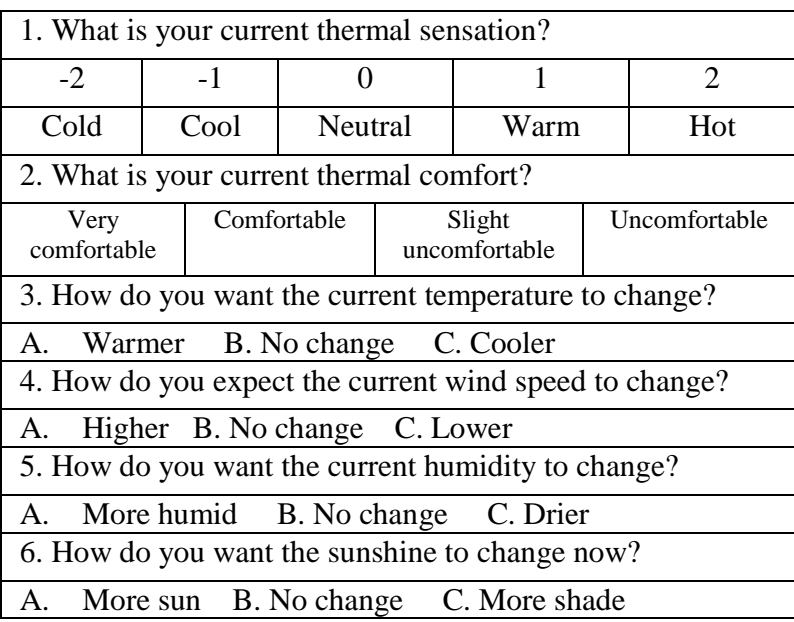

\section{Thermal comfort}

Currently, there are many evaluation indexes of thermal comfort, such as ET* (Effective Temperature), SET (Standard Effective Temperature), PMV (Predicted Mean Vote) and HSI (Heat Stress Index), wind chill index (WCI), the discomfort index (DI), and the heat stress index.

PMV, SET and other indicators have a wider range of applications in academia. SET is a general indicator that considers the activity of people and the formation of thermal resistance of clothing. It is an equivalent dry bulb temperature value, which combines the air temperature, relative humidity and average radiant temperature under the actual conditions of the thermal environment into one temperature parameter. The thermal environment conditions with different air temperature, relative humidity and average radiant temperature can be expressed by an index and compared with each other. Under the standard effective temperature, the combination of factors is different, but the thermal sensation is the same. (Liu, 2016) Ye (2003) and Honjo (2009) in their research have shown that SET and PMV are suitable for outdoor thermal environment research. For our research, we selected SET thermal comfort indicators for our thermal comfort measurement.

SET is defined as the temperature in an isothermal environment where the air temperature is equal to the average radiant temperature, its relative humidity is $50 \%$, and the air is stationary (Nastos, 2008). In this environment, a person was wearing a standard thermal resistance garment.

We conducted a questionnaire survey of residents in the settlements. Residents of the settlement included students who were attending school, working youth and retired seniors. Retired seniors were very interested in the squares of the settlement because they could resting and chatting in the shade besides the square, they feel the thermal comfort under the shade is very good. Young people are very interested in the badminton courts in the night because they can play after work and they feel the night breeze after the exercise is very comfortable. The children are very interested in the courtyard of the settlement. They feel that they can run and play in the yard. In general, the residents feel that the humidity is acceptable, the temperature under the shade is acceptable, the wind speed during the day can be higher, and the square without trees is too hot.

\section{Test results and discussion}

\section{Outdoor thermal environment}

Locations 4-9 were selected for data analysis (Figure 3). It can be seen from Figure 4 that the temperature trend of the six locations is similar, but the fluctuation range is different. The average temperature at location 4 (near pine trees) was $28.41^{\circ} \mathrm{C}$, the average temperature at location 5 (near water body) was $28.51^{\circ} \mathrm{C}$. The average temperature (The average temperature is from 00:00 on July 26 to 00:00 on July 30, that add up each temperature and divide by the number.) at location 6 (on iron sheet roof) was $29.18^{\circ} \mathrm{C}$. The average temperature at location 7 (at an urban square) was $29.1{ }^{\circ} \mathrm{C}$. The average temperature at location 8 (building overhead layer) was $29.46^{\circ} \mathrm{C}$, and the average temperature at location 9 (construction dooryard) was $28.48^{\circ} \mathrm{C}$. From the distribution of average temperature, it can be seen that the average temperature at locations close to trees and water bodies were relatively low, due to the good cooling effect of trees and water. The maximum temperature at location 4 (near pine trees) was $41.91^{\circ} \mathrm{C}$. The maximum temperature at location 5 (near water body) was $44.97^{\circ} \mathrm{C}$. The maximum temperature at location 6 (on iron sheet roof) was $47.03^{\circ} \mathrm{C}$. The maximum temperature at location 7 (at an urban square) was $42.95^{\circ} \mathrm{C}$. The maximum temperature at location 8 (at a building overhead layer) was $37.54^{\circ} \mathrm{C}$, and the maximum temperature at location 9 was $36.88^{\circ} \mathrm{C}$. From the distribution of the maximum temperature, it can be seen that the temperature of locations near trees, building overhead layer and open patios were low, indicating good cooling effect in these areas under extreme hot weather.

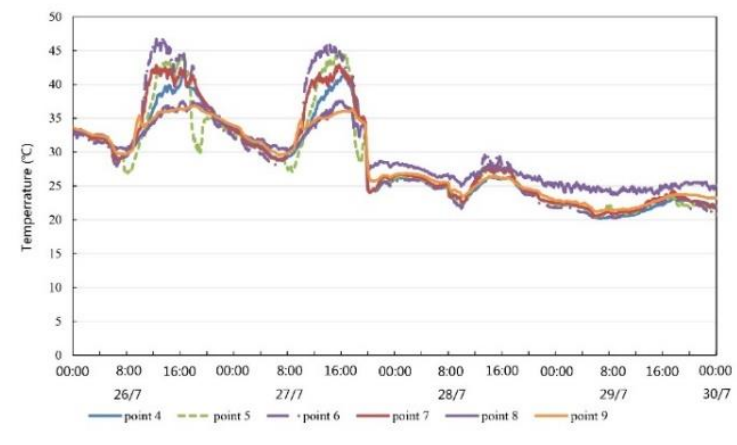

Figure 3: Temperature monitoring at locations.

In order to study the temperature level at each location, we selected location 4 (near pine trees) as the reference point, and the temperature of other locations was subtracted $\left(\Delta T_{n}\right)$ to determine the difference between the reference and other locations (Figure 4). The differences between the day and night were studied separately. From the temperature difference during the day, it can be seen that the temperature location 6 (on iron roof) was $9.46^{\circ} \mathrm{C}$ higher than that near pine trees, it can be related to the heat storage capacity of the underlying material can have a profound effect on the local ambient temperature. 
Location 7 (residential square) was $6.53^{\circ} \mathrm{C}$ warmer than near the location near pine trees, which confirms the cooling effect of trees. From the temperature difference at night, it can be seen that location 5 (near a water body) was $8.47^{\circ} \mathrm{C}$ lower than the temperature at the location near the pine trees, indicating that a small area of water can have a good cooling effect at night. Location 8 (at an building overhead layer) was $5.31^{\circ} \mathrm{C}$ cooler than near the pine trees, suggesting that the overhead layer can create a draught and reduce night temperatures. Location 9 (construction patio) was $5.9^{\circ} \mathrm{C}$ cooler than near the pine trees, it can be related to at night, the airflow from the building's patio can create a good stack ventilation effect, thereby lowering the local temperature.

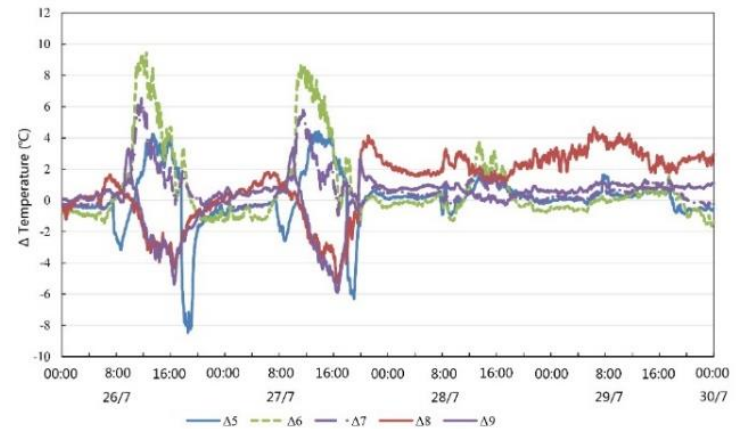

Figure 4: The difference between the temperature of each measurement location and the temperature of measurement location 4.

According to the wind speed measurements at the residential square on July 27 (Figure 5), during the daytime hours, the average wind speed in the square area was $1.16 \mathrm{~m} / \mathrm{s}$. This wind speed may provided residents with a more comfortable wind environment. Which model of residential area provided residents with a more comfortable wind environment? We proposed the following assumptions: (1) The open space should be set aside in the residential area, which is conducive to the wind. (2) The floor space may affect the wind speed. The architect needs to set the floor spacing according to factors such as sunshine, wind speed, economy, and land utilization. (3) Reasonable matching of buildings of different heights may affect the wind environment of the residential area, thereby improving the wind environment of dwelling district.

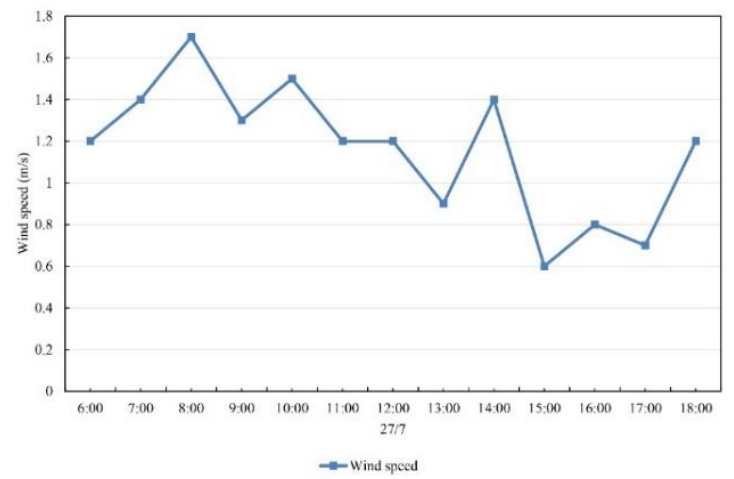

Figure 5: Wind speed at the residential square.
We set the standard clothing thermal resistance as 0.6 clo. The SET temperature data during the daytime of 27 July was as shown in Figure 6. Combining with the standard data of Table 5, when temperature was higher than $37.5^{\circ} \mathrm{C}$ the human body would feel hot and uncomfortable. It can be seen from Figure 7 that the proportion of uncomfortable outdoor heat was high, therefore would require a further increase in the green area, to reduce the outdoor temperature. (Tan, 2017) When the temperature was between $30^{\circ} \mathrm{C}$ and $34.5^{\circ} \mathrm{C}$, the human body would feel warm and uncomfortable.

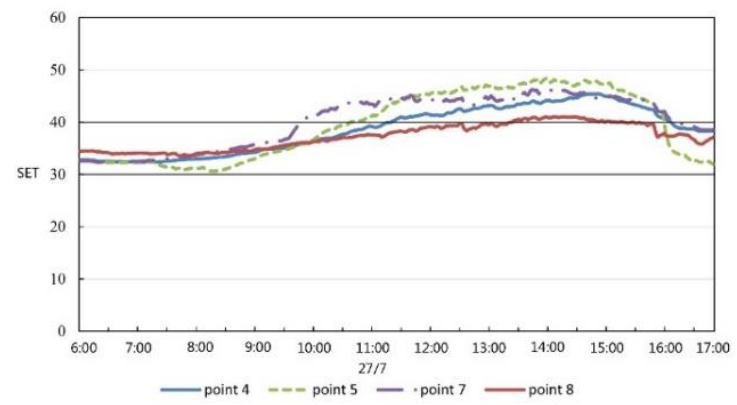

Figure 6: SET data during the daytime of 27 July.

\section{Conclusion}

The study was conducted to investigate the outdoor thermal environment and thermal comfort of Xi'an Qujiang Liveable Community by field measurement monitoring and questionnaires. The main conclusions are as follows:

During the daytime, the trees have a good cooling effect, and their cooling capacity can reach $6.53^{\circ} \mathrm{C}$ (relative to the residential square temperature). Therefore, more trees should be planted, to improve the heat storage capacity of the underlying surface to reduce the heat island intensity during the day.

During the night time, water body, open floor plan and construction dooryard have good cooling effect. The temperatures at these locations were $8.47^{\circ} \mathrm{C}, 5.31^{\circ} \mathrm{C}$ and $5.9^{\circ} \mathrm{C}$ higher than the location near the pine trees which has a good cooling capacity. This shows that small areas of water body, open floor plan and building patios have better cooling capacity during the night time. At the same time, actual measurements indicate that the cooling capacity during daylight hours is limited.

The study found that different underlying surface materials and artificial architectural design elements can create different outdoor thermal environments. In outdoor environment the design of residential areas, the use of design elements such as trees, water bodies, building overhead layer and building patios can well reduce the local air temperature. During the daytime and night time, the roofing materials made of sheet iron material can cause a rapid temperature increase and should be less use, to avoid the build-up of local heat island effect in residential areas. 


\section{Acknowledgement}

The paper was supported by National Natural Science Foundation of China (grant number: 51808440), Shaanxi Province Natural Science Basic Research Program General Project (Youth) (grant Number: 2019JQ-595), "China Postdoctoral Science Foundation" (grant number: 2018M633514), "the Fundamental Research Funds for the Central Universities" (grant number: xjj2017191), "Scientific Research Support of New Teacher of Xi'an Jiaotong University" (grant number: JZ1K004).

\section{Declaration}

There is no conflict of interest.

\section{References}

Chen Z. (2016). Field Experiments and Investigation of Outdoor Human Thermal Sensation in a Typical Residential Community in Hot-Humid Climate. Journal of Computational and Theoretical Nanoscience 13(9), 6178-6184.

Földváry, Veronika. (2018). Development of the ASHRAE Global Thermal Comfort Database II. Building and Environment 142, 502-512.

Hien, W. N., Gabriela, O., Tan, E., \& Jusuf, S. K. (2017). Indoor thermal comfort assessment of naturally ventilated atriums in singapore. Architecture and Built Environment 44(1, 53-60.

Hong B, Lin B. (2015). Numerical studies of the outdoor wind environment and thermal comfort at pedestrian level in housing blocks with different building layout patterns and trees arrangement. Renewable Energy $73,18-27$.

Honjo T. (2009). Thermal comfort in outdoor environment. Global environmental research 13, 4347.

Jamei E, Rajagopalan P, Seyedmahmoudian M, Jamei Y. (2016). Review on the impact of urban geometry and pedestrian level greening on outdoor thermal comfort. Renewable and Sustainable Energy Reviews $54,1002-1017$.

Johansson E. (2006). Influence of urban geometry on outdoor thermal comfort in a hot dry climate: A study in Fez, Morocco. Building and environment 41(10), 1326-1338.

Lai D, Guo D, Hou Y, Lin C, Chen Q. (2014). Studies of outdoor thermal comfort in northern China. Building and Environment 77, 110-118.

Lee, K., \& Levermore, G. J. (2019). Sky view factor and sunshine factor of urban geometry for urban heat island and renewable energy. Architectural Science Review 62(1), 26-34.

Li K, Zhang Y, Zhao L. (2016). Outdoor thermal comfort and activities in the urban residential community in a humid subtropical area of China. Energy and Buildings 133, 498-511.

Liu N., Qin Y.. (2016). Building thermal environment.
Tsinghua University Press. Beijing (China).

Liu, Y., Stouffs, R., Tablada, A., Wong, N. H., \& Zhang, J. (2017). Comparing micro-scale weather data to building energy consumption in Singapore. Energy and Buildings 152, 776-791.

Nastos, Panagiotis T., Andreas Matzarakis. (2008). Human-biometeorological effects on sleep disturbances in Athens, Greece: a preliminary evaluation. Indoor and Built Environment 17.6, 535542.

Salata F, Golasi I, de Lieto Vollaro R, de Lieto Vollaro A. (2016). Outdoor thermal comfort in the Mediterranean area. A transversal study in Rome, Italy. Building and environment 96, 46-61.

Salata F, Golasi I, Petitti D, de Lieto Vollaro E, Coppi M, de Lieto Vollaro A . (2017). Relating microclimate, human thermal comfort and health during heat waves: An analysis of heat island mitigation strategies through a case study in an urban outdoor environment. Sustainable cities and society 30, 7996.

Sharmin T, Steemers K, Matzarakis A. (2015). Analysis of microclimatic diversity and outdoor thermal comfort perceptions in the tropical megacity Dhaka, Bangladesh. Building and Environment 94, 734-750.

Syafii N I, Ichinose M, Wong N H, Kumakura E, Kardinal Jusuf S, Chigusa K. (2016). Experimental Study on the Influence of Urban Water Body on Thermal Environment at Outdoor Scale Model. Procedia Engineering 169, 191-198.

Taleghani M, Kleerekoper L, Tenpierik M, van den Dobbelsteen A. (2015). Outdoor thermal comfort within five different urban forms in the Netherlands. Building and environment 83, 65-78.

Tan, C. L., Tan, P. Y., Wong, N. H., Takasuna, H., Kudo, T., Takemasa, Y., ... \& Chua, H. X. V. (2017). Impact of soil and water retention characteristics on green roof thermal performance. Energy and Buildings 152, 830-842.

Tong, S., Wong, N. H., Jusuf, S. K., Tan, C. L., Wong, H. F., Ignatius, M., \& Tan, E. (2018). Study on correlation between air temperature and urban morphology parameters in built environment in northern China. Building and Environment 127, 239249.

Tong, S., Wong, N. H., Tan, C. L., Jusuf, S. K., Ignatius, M., \& Tan, E. (2017). Impact of urban morphology on microclimate and thermal comfort in northern China. Solar Energy 155, 212-223.

Wang Z, Ji Y, Su X. (2018). Influence of outdoor and indoor microclimate on human thermal adaptation in winter in the severe cold area, China. Building and Environment 133, 91-102.

Wu, S. R., Greaves, M., Chen, J., \& Grady, S. C. (2017). Green buildings need green occupants: a research 
framework through the lens of the Theory of Planned Behaviour. Architectural Science Review 60(1), 5-14.

Xi T, Ding J, Jin H, Mochida A. (2017). Study on the Influence of Piloti Ratio on Thermal Comfort of Residential Blocks by Local Thermal Comfort Adaptation Survey and CFD Simulations. Energy Procedia 134, 712-722.

Xi T, Jin H, Mochida A, Ding J. (2017). Research on the influence of piloti on residential block's outdoor thermal comfort by questionnaire survey and coupled simulation method in Guangzhou, China. The IOP Conference Series: Earth and Environmental
Science. IOP Publishing 69(1), 012003.

Yang L, Yan H, Mao Y, Yang Q. (2017). Thermally comfortable climate adaptation. Science Press. Beijing (China).

Ye G, Yang C, Chen Y, Li Y. (2003). A new approach for measuring predicted mean vote (PMV) and standard effective temperature (SET*). Building and environment 38(1), 33-44.

Yu W, Li B, Yao R, Wang D, Li K. (2017). A study of thermal comfort in residential buildings on the Tibetan Plateau, China. Building and Environment 119, 71-86. 